\title{
Vulnerability in the elderly and its relationship with the presence of pain
}

\author{
Vulnerabilidade de idosos e relação com a presença de dor
}

Leticia Masson', Fabiana Meneghetti Dallacosta²

DOI 10.5935/2595-0118.20190038

\section{ABSTRACT}

BACKGROUND AND OBJECTIVES: In Brazil, there is a high prevalence of pain in people above the age of 60 , and although pain is not related as a direct factor of dependence and death, it interferes in several aspects of life with functional limitations. This study aimed to evaluate the vulnerability of the elderly and its relation to the presence of pain.

METHODS: A survey with individuals over 60 years using the Vulnerable Elders Survey questionnaire for vulnerability analysis and the Pain-Related Disability Index to analyze the interference of pain in daily activities. The data were analyzed using the Student's $t$-test, Chi-square test, and Pearson's correlation.

RESULTS: The study had 176 participants, mean age $68.3 \pm 6.8$ years, 111 women $(63.1 \%)$, and $65.9 \%$ rated their health as good. Forty-eight elderly (27.3\%) were considered vulnerable, mainly women and patients with hypertension and diabetes. The most limiting daily living activities were bending, kneeling or squatting. The highest scoring domains for limitation due to pain were related to family and household activities, and work-related activities. The domains with lower scores were related to incapacity for sexual life and personal care. The older had lower scores on the pain scale, and the hypertensive had higher scores, as did women. There was an association between pain and vulnerability $(\mathrm{p}=0.00)$.

CONCLUSION: Pain impacts the life of the elderly, causing suffering and disability for activities of daily living, besides increasing vulnerability.

Keywords: Elderly, Health vulnerability, Pain.

Leticia Masson - Dhttps://orcid.org/0000-0001-9205-9816;

Fabiana Meneghetti Dallacosta - (Dhttps://orcid.org/0000-0003-3515-9225.

1. Universidade do Oeste de Santa Catarina, Curso de Enfermagem, Bolsista do Programa UNIEDU, Joaçaba, SC, Brasil.

2. Universidade do Oeste de Santa Catarina, Docente do Programa de Mestrado em Biociências e Saúde, Joaçaba, SC, Brasil.

Submitted on March 21, 2019.

Accepted for publication on June 11, 2019

Conflict of interests: none - Sponsoring sources: none.

Correspondence to:

Avenida Getúlio Vargas, 2125

89600-000 Joaçaba, SC, Brasil.

E-mail: fabiana.dallacosta@unoesc.edu.br

(C) Sociedade Brasileira para o Estudo da Dor

\section{RESUMO}

JUSTIFICATIVA E OBJETIVOS: No Brasil observa-se alta prevalência de dor em indivíduos acima de 60 anos, e embora a dor não apareça como fator direto de dependência e morte, causa interferência em diversos aspectos da vida e relaciona-se com limitaçôes funcionais. O objetivo deste estudo foi avaliar a vulnerabilidade de idosos e relacionar com a presença de dor.

MÉTODOS: Pesquisa com indivíduos acima de 60 anos, utilizando o questionário Vulnerable Elders Survey para a análise da vulnerabilidade e o Índice de Incapacidade relacionado com a dor para a análise da interferência da dor nas atividades de vida. A análise dos dados foi através dos testes $t$ de Student, Qui-quadrado e Correlação de Pearson.

RESULTADOS: Participaram do estudo 176 indivíduos, média de idade 68,3 $\pm 6,8$ anos, 111 mulheres (63,1\%), e 65,9\% avaliaram sua saúde como boa. Quarenta e oito idosos (27,3\%) foram considerados vulneráveis, principalmente mulheres e portadores de hipertensão e diabetes. As atividades de vida diária com maior limitação foram curvar-se, ajoelhar-se ou agachar. Os domínios de maior pontuação para limitação devido à dor foram relacionados à família e atividades domésticas, e atividades relacionadas ao trabalho. Os domínios com menores pontuações foram relacionados à incapacidade para vida sexual e cuidados pessoais. Os mais velhos tiveram menor pontuação na escala de dor e os hipertensos tiveram pontuação maior, assim como as mulheres. Houve associação entre presença de dor e vulnerabilidade $(\mathrm{p}=0,00)$.

CONCLUSÁO: A dor impacta a vida dos idosos, causando sofrimento e incapacidade para as atividades da vida diária, além de aumentar a vulnerabilidade.

Descritores: Dor, Idoso, Vulnerabilidade em saúde.

\section{INTRODUCTION}

In Brazil, there is a high prevalence of pain in individuals over 60 years old, and although pain does not show up as a direct factor of dependence and death, it interferes in several aspects of life and is related to functional limitations ${ }^{1}$.

Vulnerability increases the susceptibility to illness, impacts on the life of elderly people, and can be defined as a reduction in the capacity for self-determination, with lack of power, intelligence, education, resources, strength or other attributes ${ }^{2}$. This issue has been the object of several studies, but there is little research addressing the influence of pain on the vulnerability of the elderly. It is known that chronic pain affects the elderly's autonomy, compromising daily life activities (DLA), and impacting the quality of life $\mathrm{e}^{3}$.

In the presence of pain, old adults tend to become more vulnerable because they will have losses in performing DLA, as 
well as restricting social interaction, increasing cocooning, and compromising functional status. Pain and chronic health conditions also increase the chance of complications such as anxiety, depression, abuse of substances, and social isolation, which in turn, have an impact on the elderly's quality of life ${ }^{4}$. Identifying the presence and impact of pain in elderly people has been challenging. Pain is subjective and involves physical, psychic, and cultural mechanisms. The International Association for the Study of Pain (IASP) considers pain as an unpleasant, sensorial and emotional experience, associated or not to actual or potential tissue damage, and may be acute or chronic when it lasts for more than six months or exceeds the expected recovery period ${ }^{5}$.

Thus, this study aimed to analyze the vulnerability of older people and relate it to the presence of pain.

\section{METHODS}

A cross-sectional study, conducted with individuals over 60 years of age, living in the city of Ouro, Santa Catarina. The city has 477 hypertensive patients, and 107 people with diabetes enrolled in the Family Health Strategy and the Hiperdia program. Data collection was performed in the first half of 2018, through home visits and at the Health Unit, with questionnaires used by the researchers. The inclusion criteria were aged above 60 years, being registered at the Health Unit and living in Ouro/SC. The exclusion criteria were people who could not communicate to answer the questionnaires or who did not agree to participate in the study.

A total population of 584 individuals (hypertensive and/or diabetic) was considered to calculate the sample. The confidence level adopted was $95 \%$, and a sample error of $5 \%$., The sample size was of 174 individuals, considering the homogeneous population.

Two instruments were used, one for vulnerability analysis, Vulnerable Elders Survey (VES13), and a questionnaire for pain analysis (Pain-Related Disability Index). The VES13 has 13 items that include self-perception of health, presence of physical limitations, and functional decline, classifying the elderly in two groups: vulnerable (VES13 $\geq 3$ ) and non-vulnerable (VES13<3). This questionnaire was developed aiming to identify the vulnerable elderly, and it was validated in Brazil by Maia et al. ${ }^{6}$, proving to be reliable and easy to apply.

The Pain Disability Index, (PDI), is an instrument that evaluates and measures the degree of interference of pain in seven DLAs, by a Likert scale from zero to 10 , being zero no interference in the activity and 10 , total interference. This instrument has been widely used because it is easy to apply and good psychometric properties. It was validated for Portuguese by Azevedo et al. ${ }^{7}$

Those who agreed to participate answered the questionnaires only once, after completing the Free and Informed Consent Term (FICT).

This research was approved by the Ethics Committee of the Universidade do Oeste de Santa Catarina (UNOESC), with opinion no. 2.670.513.

\section{Statistical analysis}

The numerical data were analyzed by the Student's $t$-test and the categorical data by the Chi-square. Pearson was used for the correlation of the quantitative variables. The SPSS software was used.

\section{RESULTS}

A total of 176 individuals participated in the study, with an average age of $68.3 \pm 6.8$ years, 65 men $(36.9 \%), 111$ women (63.1\%), 167 white (94.9\%), 170 having children (96.6\%), $173(98.3 \%)$ with income between one and two minimum wages, $123(69.9 \%)$ married or living with a partner, 162 (98.3\%) with low schooling (less than eight years of study). Table 1 shows the other characteristics of the population surveyed.

Self-perception of health, according to the VES13 questionnaire, showed that $65.9 \%$ considered their health "good", 15.9\% "regular", 6.8\% "poor", 6.3\% "very good" and 5.1\% "excellent". Regarding vulnerability, 48 (27.3\%) were considered vulnerable and 128 were non-vulnerable (72.7\%) (Table 2).

Table 3 shows the vulnerability analysis according to the VES13 questionnaire. There was no association of vulnerability with marital status ( $\mathrm{p}=0.11)$, nor with schooling $(\mathrm{p}=0.25)$.

Regarding the pain scale, the domains with higher scores were incapacity for activities regarding household chores, work, and family activities. The domains with lower scores were related to the incapacity for sexual life and personal care (bathing, dressing, etc.) (Table 4).

When relating the pain scale with age, it was observed that there was a weak and inverse correlation $(\mathrm{r}=-0.1 ; \mathrm{p}=0.02)$ so that the older individuals had a lower score on the pain scale. The hypertensive patients had higher scores on the pain scale $(\mathrm{p}=0.05)$, as well as those considered vulnerable $(\mathrm{p}=0.00)$. There was no difference in the pain scale for gender $(\mathrm{p}=0.10)$. Table 5 shows the analysis of the pain scale score by gender, vulnerability, and the presence of chronic non-communicable diseases.

Table 1. Sociodemographic and clinical characteristics of elderly residents in Ouro, SC $(n=176)$

\begin{tabular}{lc}
\hline Characteristics & $\mathrm{n}(\%)$ \\
\hline Diabetic & $28(15.9)$ \\
Take drugs for diabetes & $26(92.8)$ \\
Hypertensive & $95(54)$ \\
Take drugs for hypertension & $93(9.2)$ \\
Participate in the Hiperdia group at FHS & $15(8.5)$ \\
Smokers & $12(6.8)$ \\
Ex-smokers & $30(17)$ \\
Use of alcohol & $35(19.9)$ \\
Sedentary & $55(31.3)$ \\
Do exercises occasionally & $107(60.8)$ \\
Healthy diet & $127(72.2)$ \\
\hline FHS = Family Health Strategy.
\end{tabular}

FHS = Family Health Strategy. 
Table 2. Level of difficulty for the daily instrumental activities, according to the VES13 questionnaire

\begin{tabular}{|c|c|c|c|c|c|}
\hline Activity - level of difficulty & $\begin{array}{l}\text { None } \\
\mathrm{n}(\%)\end{array}$ & $\begin{array}{l}\text { Little } \\
\text { n (\%) }\end{array}$ & $\begin{array}{c}\text { Medium } \\
\mathrm{n}(\%)\end{array}$ & $\begin{array}{l}\text { Much } \\
\mathrm{n}(\%)\end{array}$ & $\begin{array}{c}\text { Unable } \\
\mathrm{n}(\%)\end{array}$ \\
\hline Bending, kneeling, or squatting & $66(37.5)$ & $36(20.5)$ & $13(7.4)$ & $42(23.9)$ & $19(10.8)$ \\
\hline Lifting/carrying $5 \mathrm{~kg}$ objects & $117(66.5)$ & $14(8)$ & $09(5.1)$ & $25(14.2)$ & $11(6.3)$ \\
\hline Raise/extend arms above shoulder & $101(57.4)$ & $18(10.2)$ & $14(8)$ & $24(13.6)$ & $19(10.8)$ \\
\hline Writing/holding small objects & $167(94.9)$ & $01(0.6)$ & $04(2.3)$ & $04(2.3)$ & - \\
\hline Walk 400 meters & $108(61.4)$ & $26(14.8)$ & $15(8.5)$ & $26(14.8)$ & $01(0.6)$ \\
\hline
\end{tabular}

Table 3. Vulnerability according to the VES13

\begin{tabular}{|c|c|c|c|}
\hline Variables & $\begin{array}{c}\text { Vulnerable } \\
\mathrm{n}(\%)\end{array}$ & $\begin{array}{c}\text { Non-vulnerable } \\
\mathrm{n}(\%)\end{array}$ & $p$-value \\
\hline $\begin{array}{l}\text { Gender } \\
\text { Female } \\
\text { Male }\end{array}$ & $\begin{array}{l}36(75) \\
12(25)\end{array}$ & $\begin{array}{l}75(58.5) \\
53(41.4)\end{array}$ & $<0.05$ \\
\hline $\begin{array}{c}\text { Age (years) } \\
60-79 \\
>80\end{array}$ & $\begin{array}{l}44(91.6) \\
04(8.4)\end{array}$ & $\begin{array}{c}118(92.1) \\
10(7.9)\end{array}$ & 0.56 \\
\hline $\begin{array}{c}\text { Diabetic } \\
\text { Yes } \\
\text { No }\end{array}$ & $\begin{array}{l}13(20.8) \\
35(79.2)\end{array}$ & $\begin{array}{c}15(11.8) \\
113(88.2)\end{array}$ & $<0.05$ \\
\hline
\end{tabular}

${ }^{*}$ Chi-square test.

Table 4. Level of incapacity for activities due to the presence of pain

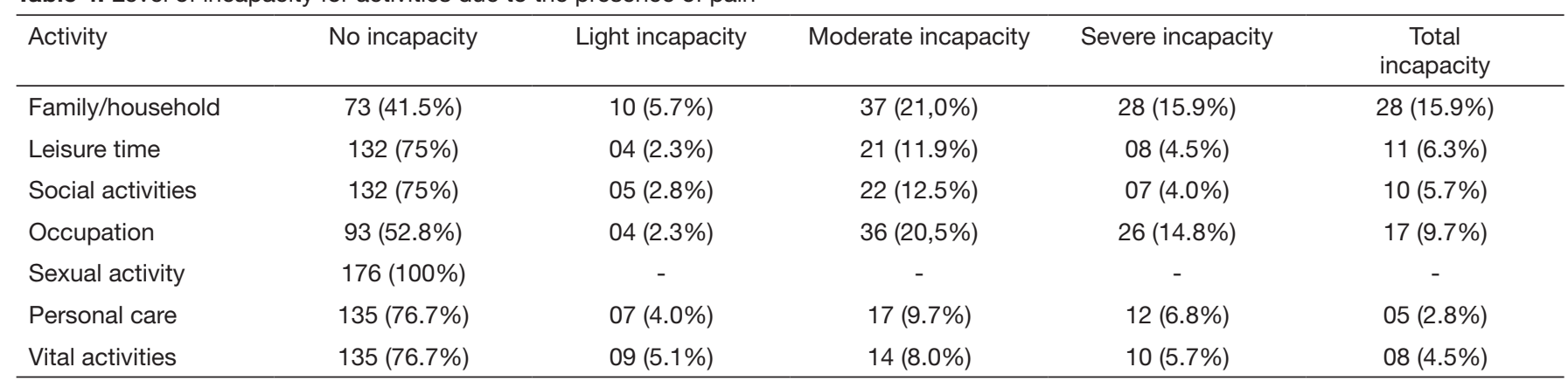

Table 5. Analysis of the pain scale score by gender, vulnerability, and the presence of chronic non-communicable diseases

\begin{tabular}{lcc}
\hline Variables & $\begin{array}{c}\text { Score on the } \\
\text { pain scale }\end{array}$ & p-value \\
\hline Gender & $12.7 \pm 6.4$ & 0.10 \\
$\quad$ Female & $11.2 \pm 5.1$ & \\
Male & & \\
Vulnerable & $17.2 \pm 6.1$ & 0.00 \\
$\quad$ Yes & $10.3 \pm 4.8$ & \\
No & & \\
Diabetics & $13.0 \pm 6.5$ & 0.44 \\
Yes & $12.0 \pm 5.9$ & \\
No & & \\
Hypertension & $13.0 \pm 6.5$ & 0.05 \\
$\quad$ Yes & $11.2 \pm 5.2$ & \\
No & &
\end{tabular}

\section{DISCUSSION}

The main outcomes of this study showed a significant association between incapacity due to pain with vulnerability and the presence of hypertension. Studies suggest that pain is mainly associated with the female gender, advanced age, and low socioeconomic status, but in this study, the younger individuals had more complaints of incapacity due to pain ${ }^{8}$.

The activities reported by the elderly as more difficult are bending, kneeling or crouching and raising/extending the arms above the shoulder. Less difficulty was reported for writing or holding small objects. These difficulties do not seem to interfere in the self-perception of health since $65.9 \%$ considered their health good. It is known that self-perception of health depends on sociodemographic variables, morbidities and social support, as well 
as the functional capacity is associated with physical activity, nutritional status, and the number of chronic non-communicable diseases. In this way, the perception of health is individual and affected by several factors ${ }^{9}$.

Impaired mobility is one of the most disturbing events in the health of the elderly, associated with reduced strength and muscular power, disability, and dependence to perform daily activi$\operatorname{ties}^{10}$. The incapacity to perform daily activities limits the autonomy of the elderly, diminishes the quality of life and increases the risk of dependence, care, and premature death ${ }^{11}$.

In the studied population, the highest prevalence was of non-vulnerable individuals, highlighting that the most vulnerable were female. Despite being a universal process, aging has a strong relationship with gender, where women tend to have a longer life expectancy than men, with important characteristics in the old age that make them more vulnerable. Although women have higher life expectancy than men, the proportion of years lived with the disease is also higher ${ }^{12}$.

Regarding chronic non-communicable diseases, it is estimated that $85 \%$ of the elderly have at least one, and they constitute an important risk to health ${ }^{13}$. With the increase in the longevity of the population, the aggregation of several risk factors can compromise the quality of life of the elderly, and when comorbidities are present, the possibility of decline is higher, since the ability to compensate a problem is affected by the accumulation of diseases ${ }^{2}$. Concerning the marital status, widowers are more likely to be vulnerable, because the death of a family member may be negative for health, leading to cocooning ${ }^{14}$, but this was not observed in this study.

Although the percentage of elderly people with difficulty to perform DLA was not expressive in this study, it is important to encourage the elderly population to practice physical activities to improve their physical fitness. Regular exercises delay the degeneration of muscles, ligaments, bones, and joints, providing stronger muscles, flexible joints, and maintaining balance and coordination, allowing greater mobility and independence. Also, exercises help the elderly to keep themselves flexible, active, and in good shape ${ }^{12}$.

In this study, it was observed that pain led to incapacity mainly in issues related to family, work, and domestic activities. It is known that pain is one of the main factors that limit the elderly to have a normal life, and causes impairment in the performance of DLA, restricts social interaction, and compromises the functional status ${ }^{1}$.

Some limitations of the study include the cross-section nature, the analysis of a specific period, and the fact that the presence of chronic pain was not investigated, but the incapacity due to pain.

\section{CONCLUSION}

This study found a correlation between vulnerability and women, the presence of hypertension and diabetes; while the pain-related incapacity was higher in the younger elderly, the hypertensive and those considered vulnerable.

\section{REFERENCES}

1. Barbosa KT, Costa KN, Pontes ML, Fernandes MG. Envelhecimento e vulnerabilidade individual: um panorama dos idosos vinculados à Estratégia Saúde da Família. Texto Contexto Enferm. 2017;26(2):e2700015.

2. Bonardi G, Souza VB, Moraes JF. Incapacidade funcional e idosos: em desafio para os profissionais de saúde. Incapacidade funcional e idosos: um desafio para os profissionais de saúde. Sci Med. 2007;17(3):138-9.

3. Brito KQ, Menezes TN, Olinda RA. Functional disability: health conditions and physical activity practice in older adults. Rev Bras Enferm. 2016; 69(5):773-80.

4. Celich KL, Galon C. Dor crônica em idosos e sua influência nas atividades da vida diária e convivência social. Rev Bras Geriatr Gerontol. 2009;12(3):345-59.

5. Cunha LL, Mayrink WC. Influência da dor crônica na qualidade de vida em idosos. Rev Dor. 2011;12(2):120-4.

6. Maia FO, Duarte YA, Secoli SR, Santos JL, Lebrão ML. Adaptação transcultural do Vulnerable Elders Survey-13 (VES13): contribuindo para a identificaçăo de idosos vulneráveis. Rev Esc Enferm USP. 2012;46 (spe):116-22.

7. Azevedo LF, Pereira AC, Dias C, Agualusa L, Lemos L, Romão J, et al. Traduçāo, adaptação cultural e estudo multicêntrico de validação de instrumentos para rastreio e avaliação do impacto da dor crônica. Dor. 2007;15(4):6-56.

8. Focchesatto A, Rockett FC, Perry ID. Fatores de risco e proteção para desenvolvimento de doenças crônicas em populaçấo idosa rural do Rio Grande do Sul. Rev Bras Geriatr Gerontol. 2015;18(4):779-95.

9. Garcia PA, Dias JM, Dias RC, Santos P, Zanta CC. Estudo da relação entre função muscular, mobilidade funcional e nível de atividade física em idosos comunitários. Rev Bras Fisioter. 2011;15(1):15-22.

10. Lima CA, Carvalho JL, Aquino RC. Avaliaçấo de vulnerabilidade do idoso através da adaptação transcultural do instrumento de identificaçáo do idoso vulnerável VES-12. Rev Eletr Estácio, Recife. 2017;3(1):1-7.

11. Nunes MC, Ribeiro RC, Rosado LE, Franceschini SC. Influência das características sociodemográficas e epidemiológicas na capacidade funcional de idosos residentes em Ubá, Minas Gerais. Rev Bras Fisioter. 2009;13(5):376-82.

12. Parke A, Griffiths M, Pattinson J, Keatley D. Age-related physical and psychological vulnerability as pathways to problem gambling in older adults. J Behav Addict. 2018;7(1):137-45.

13. dos Santos FA, de Souza JB, Antes DL, d'Orsi E. Prevalence of chronic pain and its association with the sociodemographic situation and physical activity in leisure of elderly in Florianópolis, Santa Catarina: population-based study. Rev Bras Epidemiol. 2015;18(1):234-47. English, Portuguese.

14. Vilela DA, Vilela IP, Tamtmatsu-Rocha JC, Tatmatsu DI, Vilela MP, Marque RP. Percepçáo da saúde e dor em idosos em unidades de saúde. Rev Port Ciências Desporto. 2017;S2.A:54-6. 